\title{
Study of Dependency of Newspapers on News Agency Sources Regarding Science News and all Other News in Asia and Africa in the Last Decade: A Comparative Study
}

\author{
Prof. (Dr.) Tapati Basu \\ Professor, Department of Journalism and Mass Communication, University of Calcutta, Senate \\ House, College Street, Kolkata, West Bengal, India
}

\section{Ratul Datta}

Ph.D. Research Scholar, Department of Journalism and Mass Communication, University of Calcutta and Govt Gazetted Officer, Information \& Cultural Affairs Department, Govt of West Bengal,

Writers' Buildings, Kolkata, India

\begin{abstract}
In this research, the main objective is to explore the need of the pedagogic study of growing interest in science communication as an area of specialization in the newspapers of Asian and African countries with main focus on dependence on news agency journalism as the main news source of that science news in the last decade. Compared to the Asian and African scenario it is found that, world has already experiencing a widespread diffusion of such activities for sustainable development. Whether science journalism is one of the numerous casualties in the media meltdown in the world is the most pertinent question of the last decade of $21^{\text {st }}$ century. This study involved a survey of 14 most circulated English newspapers from 14 selected Asian countries with 14 different news agency from each country and their dependency were analyzed. Similarly, for African countries, 14 another circulated English newspaper from 14 selected African countries with 14 another news agency were listed and the dependency of those newspapers for science news and all other news were critically analyzed and lastly compared with Asian countries. It has been found that, when, for all other news, newspaper management depend only on their own sources and correspondents and they spend huge amount of money for that, for science news only, they publish only what agency had sent and then more or less the tone of all copies are same in all newspapers, and readers are deprived of better science news.
\end{abstract}

Keywords: Pedagogic, News agency, Asian, African, Sustainable, Development, Newspaper management, Science news

\section{INTRODUCTION}

What is freedom of speech and freedom of expression? Freedom of speech is the right to articulate one's opinions and ideas without fear of government retaliation or censorship, or societal sanction. Freedom of expression is sometimes used synonymously, but includes any act of seeking, receiving and imparting information or ideas, regardless of the medium used. It is to be kept in mind that, only media can give the freedom of speech and expression.

Here comes the role of any news agency. News agency is nothing but such an organization or system or company which has their own correspondent and reporters for collection of all types of news (as far as possible) and selling tie-up with media houses. It may be newspaper, any broadcast or telecast media or even any web journal also. It is nothing but a wire service and needless to say that all subscriber get same news at a time in the same language. It is needless to say that, there are mutual interests among all newspapers, news personnel and media houses regarding the study on news agency and free flow of global information system. But why news agency? Why there is a need of free flow of information? It refers to the McBride Commission and UNESCO publication, "Many Voices, One World". Regarding the information imbalances, the program web site states that it "exists to strengthen the means of mass communication in developing countries, by increasing technical and human resources for the media, by developing community media and by modernizing news agencies and broadcasting organizations." News agency concept was globally accepted only because of the reason to create opportunities for the elimination of global poverty and the greater capacity for 
citizens of the world to bear witness to and fight against violations of human rights, wherever they may happen. But if there is over dependence on news agency only and voice of local correspondents are negligible for science news, scenario will differ, if is an African or Asian country.

This research paper sets out to investigate the extent to which the Asian and African English newspapers rely on transnational wire services. This study will test the following hypothesis: whether the Asian and African English Newspapers have over-dependence on news agencies for science news for stories from around the world rather than all other news and for Africa, whether this dependency is much more than Asian countries. It has been always kept in mind that, the freedom of people to express their opinions is fundamental to and inseparable from the existence of a healthy democracy that respects human rights. If people are unaware about local scientific developments from local correspondents, expressing their views becomes questionable.

\section{BACKGROUND OF THE STUDY}

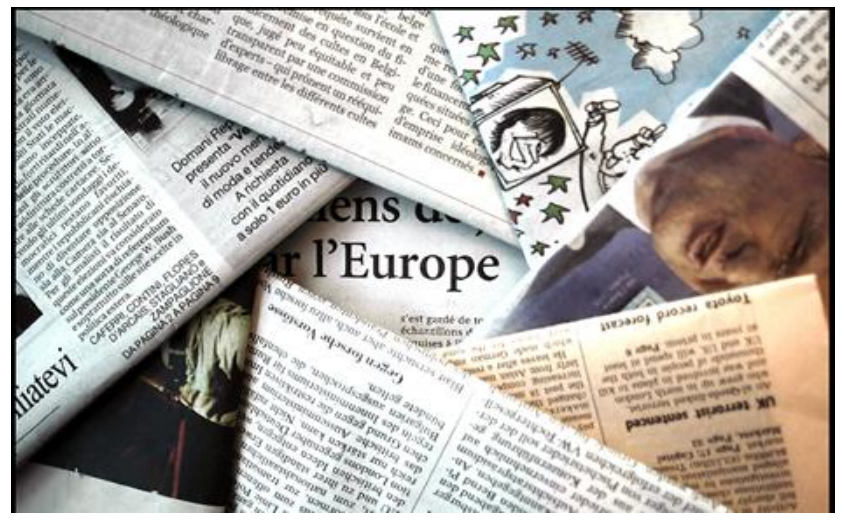

A time series analysis at the macro level since 20 years i.e. from 1986 to 2016 revealed that the dependency on news agency is totally different for television and newspaper i.e. print media. Television viewership increased rapidly since 1995 and becomes saturated more or less after 2002. On the other hand, the momentum in readership was remarkably visible from 2000 and more marked after 2002. Hence, different study will show that, dependency on news agency of the newspapers has also been increased, despite the boom in the number of channels and networks. Although 61st World Newspaper Congress (June 2008) maintained that "newspaper circulation has been rising or stable in three quarters of the world's countries over the past five years", one cannot ignore that the rise of the Internet and shrinking attention spans are causing concern for newspapers in USA and Europe.

What is a free newspaper? A free media and a free newspaper ensure the freedom of speech and expression. Although, more or less, every newspaper depends on news agency sources, it is the scenario of China, India and Japan, which is keeping the upbeat trend of newspapers. India is the second largest country after China regarding national readership survey and it has pointed that younger generation spends more time on Internet and web version of newspapers. Many more countries of Asia and Africa have direct control on every media, of their Government and they bound to publish pro-govt news, it is on science also. Here comes the most important question on science journalism that, if only 3-4 \% space is allotted for science news in South-east Asian countries, and if they depend only on news agency sources (as the recruitment of science journalist is decaying gradually), what will be the scenario of African countries, has to be investigated.

In broad terms, the study underscores the consensus on major Asian countries on one hand, and African countries on the other hand. The research method used for this study is mainly the content analysis of all published news in the selected newspapers of the selected countries which is a very frequently used approach in media studies. It allows the researcher to put the content of the media about science news on the one hand and all other news on the other hand, in this case the newspapers of Asian and African countries and the news of news agencies, under the microscope and obtains quantitative results. The all news of those newspapers will be compared against that of science news on the basis of dependency on news agency. It will be find out that whether for all news, agencies' copy is fully published or they depend on their own source, which is more important and becomes objective to any reader and what is the condition for science news, whether they get same importance to that newspaper house. 


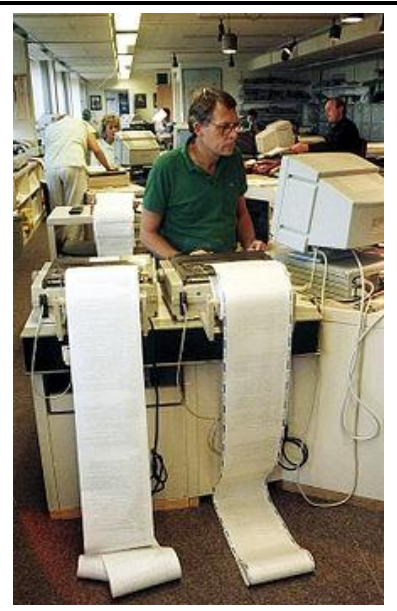

\section{Materials}

For the research work, it is not possible to have all the countries of Asia and Africa as the sample space. Further it is too tough to analyze all news of all agencies of all newspaper published from those countries, who subscribe news from news-agency.

\subsection{Asian Countries}

China, India, Japan, Afghanistan, South Korea, Saudi Arabia, Iran, Pakistan, Bangladesh, Thailand, Russia, North Korea, Indonesia and Israel were chosen. Then for the news agencies of those countries: Xinhua News Agency for China, Press Trust of India i.e. PTI for India, Kyodo News for Japan, Bakhtar News Agency for Afghanistan, Yonhap News Agency for South Korea, Saudi Press Agency for Saudi Arabia, FARS for Iran, Associated Press of Pakistan for Pakistan, Bangladesh Sangbad Sangstha for Bangladesh, MCOT Public Company Limited for Thailand, Russian News Agency TASS for Russia, Korean Central News Agency for North Korea, Antara for Indonesia and jns.org for Israel were chosen. Below is the brief background of those news agencies.

Bakhtar News Agency is situated in Kabul and the only official state news agency of Afghanistan. More or less, all big and medium newspaper of English language truly depends on that news agency for national and international news agency. This agency is monitored by Ministry of Culture and Information of that country. Newspapers mostly depend on what this agency sent to their office and recruit fewer correspondents for local news. Agence France-Presse established a satellite link providing news information to the Bakhtar News Agency.

Xinhua News Agency is one of the most important and official news agencies of the People's Republic of China. It is to be noticed that it is also the biggest and most influential set-up of that country. It is the institution at ministry level under Chinese central government. It has more than 170 foreign bureaus throughout the world and in China; it has 31 different bureaus also, for each province. It has a military bureau also. In China and their Chinese central government, Xinhua is the most important and dependable agency to cater all types of news.

Saudi Press Agency is the most important and official news agency of Saudi Arabia. The first news agency of Saudi Arabia, it was established in 1970. It is also the first news agency in the Persian Gulf region. Ministry of Information and Culture of this country has the responsibility of this agency and hence, its president, reports to the ministry directly regarding any problem. It has both Arabic and English version to cater news. Information and Cultural Minister of this country is the board chairman of this agency.

Associated Press of Pakistan (APP) is the most important and also government-operated national news agency of Pakistan. There should be no confusion that, Associated Press news agency (AP) is the another larger agency with which APP cannot be related. AP is based in New York and APP is in Pakistan. APP has five bureau offices at Karachi, Lahore, Peshawar Quetta and Rawalpindi. It has seven news centres at Sukkur, Multan, Quetta, Faisalabad, Larkana, Hyderabad, Muzaffarabad and now Gilgit-Baltistan also. 
MCOT Public Company Limited (MCOT) was formerly known as or renamed as Mass Communication Organization of Thailand (M.C.O.T.). It is one of the public broadcasters of Thailand. This company has also a number of Radio and Television stations as ownership and their main office is at Bangkok. MCOT has seven national, one international, 52 provincial, one district radio station, two television channels, which is terrestrial and free to air and 2 satellite television channels.

Bangladesh Sangbad Sangstha (BSS) is national news agency of the neighbouring country Bangladesh. It was established on $1^{\text {st }}$ January, 1972, as soon as it got the independence through war, from Pakistan. Generally the managing director becomes the editor of this company.

Kyoto News Agency is the most important news agency of Japan and is based in Minato, Tokyo. In November 1945, it was established and presently it distributes all types of news, including science news to almost all the newspapers, broadcast and audio-visual media of that country. Presently this agency has about more than 5 crore subscribers. This agency has the one business arm as K K Kyodo News and their online news site is in Japan, China, Korea and in English.

PTI i.e. Press Trust of India is the most important and the largest news agency in India. It has it's headquarter in Sansad Marg of New Delhi and it sells all types of specialized news to more than 500 Indian newspapers. It has its service in both English and Hindi version. PTI has its agency offices in Bangkok, Beijing, Colombo, Dubai, Islamabad, Kuala Lumpur, Moscow, New York and Washington D.C. Only PTI has its own communication satellite in South-east Asia, an INSAT, to collect and disseminate all news and information.

Russian News Agency TASS is the major news agency in Russia and it was founded in the year 1902. It is very important to say that, it is the largest news agency of Russia. It is also the fourth largest news agency in the world, after Reuters, Associated Press and Agence France Presse. Tass is owned by the Government of Russia and its head quarter is at Moscow. All over Russia, Tass has more than 70 offices and also 68 bureau office around the world. Tass is also the Federal State Unitary Enterprise.

JNS.org is a non-profit wire service which covers Jewish and Israel all types of news for the English speaking world and also independent. This news agency generally covers Jewish news from America, Europe, Israel and other countries also. It sends all types of latest news and briefs and major features to Israel, the Middle East and the Jewish world. It is considered as the major secular publications for Jewish, Christian and others also.

Fars News Agency (FNA) is one of the major important news agencies in Iran. It is considered as the semi official and major leading independent news agency of the country, Iran. Founded in 2003, Fars News Agency provides all types of news in English, Turkish and in Arabic also.

Yonhap News Agency is the largest news agency of South Korea. Based in the city, named Seoul, Yonhap is the publicly funded company of this country. It provides all news articles, pictures, all types of information to print media, electronic media and audio-visual media. It is the only Korean wire service that works with foreign news agencies. It also provides a free and limited flow of information to the websites of Korean, English, Chinese, Japanese, Spanish, Arabic and French.

Antara is the news agency of Indonesia and also the private owned company under the Ministry of State-owned Enterprises of this country. Indonesia's most important national news agency is Antara. The news agency is too old in the country and was founded in the year 1937. At that time, the country Indonesia was a colony of the Dutch Empire and Dutch-owned Aneta was a news agency and people were dissatisfied for the local news coverage.

\subsection{African Countries}

Algeria, Angola, Ethiopia, Ghana, Namibia, Nigeria, Senegal, South Africa, Kenya, Mongolia, Morocco, Tunisia, Sudan and Egypt were chosen. Then for the news agencies of those countries: Algerian Press Service for Algeria, Angola News Agency for Angola, Ethiopian News Agency for Ethiopia, Ghana News Agency for Ghana, Namibia Press Agency for Namibia, News Agency of Nigeria for Nigeria, Pan African News Agency for Senegal, African News Agency for South Africa, Kenya News Agency for Kenya, Montsame for Mongolia, Maghreb Arab Press for Moroco, Tunis Afrique Presse for Tunisia, Sudan News Agency for Sudan and Middle East News Agency for Egypt were chosen. Below is the brief background of those news agencies. 
Study of Dependency of Newspapers on News Agency Sources Regarding Science News and all Other News in Asia and Africa in the Last Decade: A Comparative Study

Algeria Press Service is the news agency of one of the African country, Algeria. It was created in 1961 on $1^{\text {st }}$ December in Tunis with a strong background of Algerian war of Independence and African war of Revolution. It uses the nation's national flag colours as symbol and from $1^{\text {st }}$ January, 2009 , this agency covers all types of news of the Algerian territory.

ANGOP or Angola News Agency is the official news agency of the state of Angola, based in Luanda. Founded in 1975, it was a former close ally of the now-defunct official news agency of the Soviet Union, the Telegraph Agency of the Soviet Union (TASS). It is part of the Alliance of Portuguese-speaking News Agencies. ANGOP was a member of the Non-aligned News Agency Pool, an organisation that drew its members from over 100 countries. In 1991, it regained its autonomy and editorial independence under their law.

Ethiopian News Agency (ENA) is the official news agency of the Government of Ethiopia. It is the oldest news organization in Ethiopia.

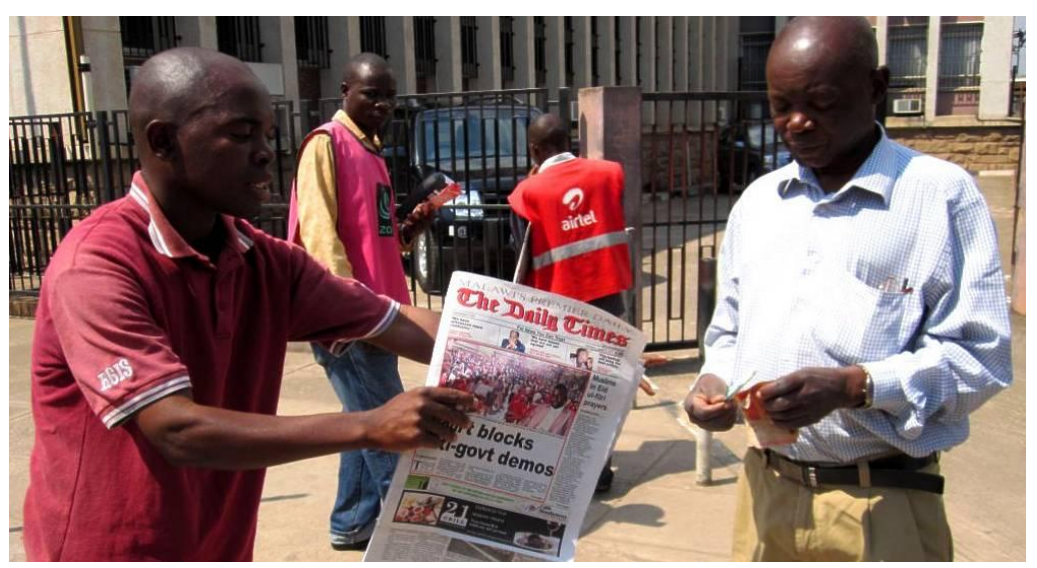

Ghana News Agency (GNA) is the most important news agency of the country of Africa, Ghana. As the coercive and one of the partisan institutes of this country, it was founded in the year 1957. Most of the Ghanaian newspapers, print media, audio and audio-visual media depend on this news agency. It has found also that, it deleted all news which questioned the government leadership of this country. In 1960, when the becomes independent, this agency also started to work independently, though this agency, still works for government only.

Namibia Press Agency (NAMPA) is the state-owned national news agency of the Republic of Namibia. This news agency in Africa was established in 1987 with the name of the Namibia Press Association as a SWAPO partisan press agency. In 1991, this news agency was renamed and present name becomes popular. This news agency is purely dependable for all types of news and picture service to all newspapers of that country. But still now, it has no audio and visual feed to cater to the media houses. Most of the media houses, for international news also, in Namibia, rely on the services of NAMPA.

News Agency of Nigeria (NAN) is the most important and state-run news agency in Nigeria. It was established in $1976,10^{\text {th }}$ May and after 5 months, on $2^{\text {nd }}$ October of the same year, it has started its operation. Nigerian media mainly depend on this agency.

Pan African News Agency is one of the most important African news agencies and situated with its head quarters at Dakar of Senegal. It was founded on 20 July 1979 in Addis Ababa by African Unity, an important organization of Africa and was relaunched by the UNESCO in 1993. In collaboration with UNESCO, it caters all information in the language of English, French, Portuguese, and Arabic. It is one of the most important and specialised news agency of the Organization of African Unity (OAU) and has its regional offices at regional offices at Khartoum, Sudan; Lusaka, Zambia; Kinshasa, Democratic Republic of the Congo; Lagos, Nigeria; and Tripoli, Libya.

African News Agency is known as the ANA and it is one of the important syndication services of African continent, it was established by two African billionaires. As soon as this news agency was launched, South African Press Association (SAPA) was liquidated and this new agency was formed. It is to be kept in mind that, SAPA was once a major contributor and seller of all foreign and domestic news in South Africa and the major medias are mostly depend on this agency for any type of news feed. 
Kenya News Agency (KNA) is national news agency which is run by their government, under the Department of Information, Ministry of Information Communication and Technology. It has it's headquarter at Nairobi and started its operation in 1963.It generally creates all national and local news at their editorial desk, and from there it is disseminated from the agency to their all subscribers around the world. Many newspapers and broadcasters are the subscribers of this African agency. Now a day, including Publications and Photographic services, Kenya News Agency has changed to Kenya News Agency and Press.

Montsame is to be considered as the state owned news agency of Mongolia. It has different mutual agreement with the different agencies like Xinhua, Information Telegraph Agency of Russia, Yonhap, Vietnam News Agency, Reuters, Prensa Latina, Bulgarian News Agency, Anadolu Agency, Polish Press Agency, Ukrinform, Azerbaijan State Telegraph Agency, Kazinform, Mehr News Agency, Voice of America and Korean Central News Agency.

Maghreb Arab Press is the official and important news agency of Morocco. This news agency has official international services in five languages: Arabic, English, French, Spanish, and Tamazight. Maghrab Arab Press started its African bulletin in the year 1960 and then it started its Middle East service on 14 October, 1975. As it is one of the most important news agencies of Africa and besides having large network throughout Asia, it has 19 international news agency and bureau offices in Abidjan, Algiers, Bonn, Beyrouth, Cairo, Dakar, Geneva, Jeddah, Lisbon, Madrid, Mexico City, Montreal, Moscow, New Delhi, Nouakchott, Paris, Rome, Tunis and Washington.

Tunis Afrique Presse (TAP) is the most important news agency of Tunisia. It was founded on 1961, 1 January. Besides news, it sends different news-based photographs to different newspapers also. It reports national and international news in Arabic, French and in English also. It is not a fully independent agency and for different international news, it has to depend on AFP, Reuters and AP i.e. Associated Press.

Next come the question of newspapers, where those science news compared to all other news were published. Hence, for Asian countries: China Daily for China, The Times of India for India, Asahi Shimbun (International Herald Tribune) for Japan, Afghanistan Times Daily for Afghanistan, The Korea Herald for South Korea, Arab News for Saudi Arabia, Tehran Times for Iran, Dawn for Pakistan, The daily Star for Bangladesh, The Nation for Thailand, The Moscow Times for Russia, The Pyongyang Times for North Korea, The Jakarta Post for Indonesia, The Jerusalem Post for Israel were chosen. On the other hand, for African countries: Algeria Daily for Algeria, News Time Africa for Angola, The Ethiopian Herald for Ethiopia, Daily Graphic for Ghana, New Era for Namibia, This Day for Nigeria, Xew Media for Senegal, Africa Herald Express for South Africa, Daily Nation for Kenya, UB Post for Mongolia, MBC Times for Morocco, The Tunis Times for Tunisia, Sudan Tribune for Sudan and Al-Ahram for Egypt were chosen.

\section{Methodology}

\section{Sample Survey Method}

The study was done on the basis of the last decade, considering the $7^{\text {th }}$ day of each month i.e. $7^{\text {th }}, 14^{\text {th }}$, 21 th and $28^{\text {th }}$ day was taken as sample of each month of each year. Hence, $4 \times 12 \times 10$ i.e. 480 samples were taken for each newspaper for 14 countries of Asia and 14 countries of Africa. It is to be kept in mind that, collection of all newspaper of Africa and Asian countries, in the sample space, in hard copy format, is not possible. So, web pages of those newspapers were considered only and then they are transformed into hard copy format in space share in column-centimetre format. Then on the basis of the following Research Questions, samples were been analyzed.

\section{RESUlTS AND DISCUSSIONS OF RESEARCH QUESTIONS}

$\boldsymbol{R Q}-\boldsymbol{I}$ Is there any science news in page-1 of the newspapers?

Table-1 on RQ-1

\begin{tabular}{|c|c|c|c|}
\hline Asia & Percent & Africa & Percent \\
\hline China & 2.0 & Algeria & 0.3 \\
\hline India & 1.1 & Angola & 0.1 \\
\hline Japan & 2.1 & Ethiop & 0.2 \\
\hline Afgha & 0.3 & Ghana & 0.6 \\
\hline S.Kor. & 1.6 & Namibia & 0.6 \\
\hline S.Arab & 0.6 & Nigeria & 1.1 \\
\hline
\end{tabular}


Study of Dependency of Newspapers on News Agency Sources Regarding Science News and all Other News in Asia and Africa in the Last Decade: A Comparative Study

\begin{tabular}{|c|c|c|c|}
\hline Iran & 0.4 & Senegal & 0.2 \\
\hline Pakistn & 0.6 & S.Africa & 1.3 \\
\hline Bngldsh & 1.0 & Kenya & 1.1 \\
\hline Thail & 1.6 & Monglia & 0.5 \\
\hline Russia & 1.9 & Morocco & 0.3 \\
\hline N.Kor. & 0.5 & Tunisia & 0.2 \\
\hline Indonsia & 0.9 & Sudan & 0.5 \\
\hline Israel & 1.1 & Egypt & 0.8 \\
\hline Total & 1.13 & Total & 0.56 \\
\hline
\end{tabular}

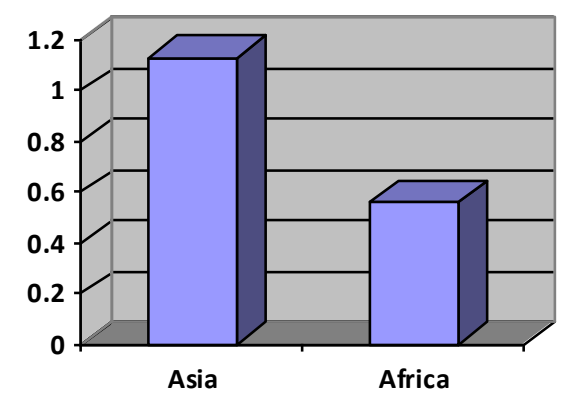

Diagram1. Comparative study of page-1 science news in Asia and Africa
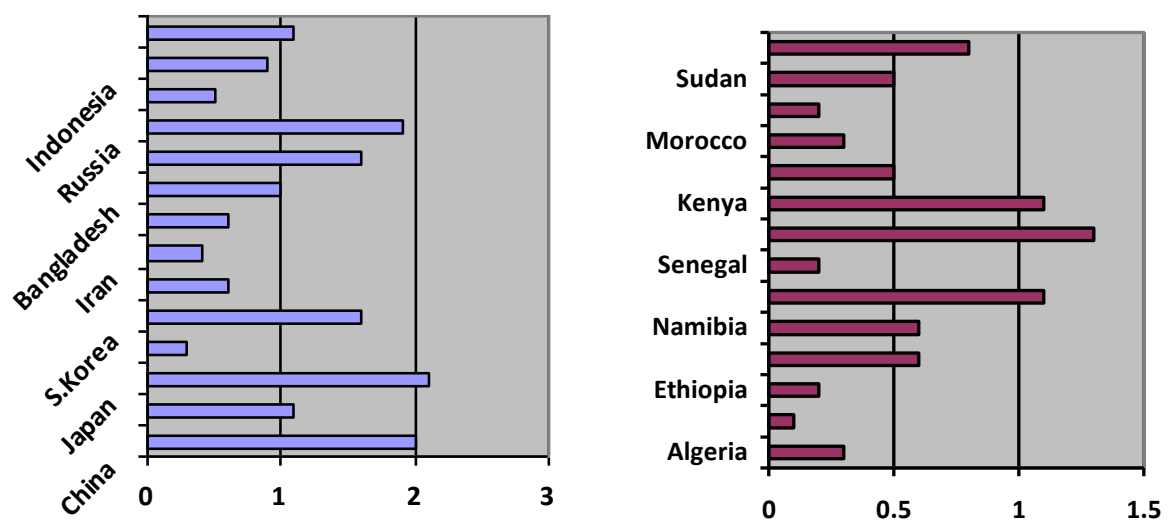

Diagram 2, 3. Comparative study of page-1 science news in most of the Asian and African countries

$\boldsymbol{R Q}$-2 Among all science news published in the $1^{\text {st }}$ page, percentage of no of science news directly copied and published, mentioning the news agency.

$\boldsymbol{R Q - 3}$ Among all science news published in the $1^{\text {st }}$ page, percentage of no of all other news directly copied from news agency, mentioning the news agency.

$\boldsymbol{R Q}$-4 Among all photographs on science news, which are from news agency.

\begin{tabular}{|c|c|c|}
\hline Research Question & Asia & Africa \\
\hline 2 & 61 & 94 \\
\hline 3 & 5 & 35 \\
\hline 4 & 81 & 96 \\
\hline
\end{tabular}

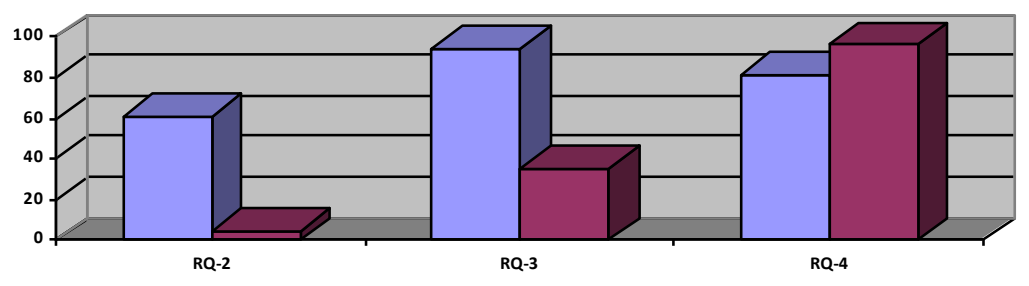


$\boldsymbol{R Q - 5}$ Is there any separate science page for science news?

\begin{tabular}{|c|c|}
\hline Asia & Africa \\
\hline 12 & 3 \\
\hline
\end{tabular}

$\boldsymbol{R Q} \mathbf{Q} \mathbf{6}$ A comparative study in the number of all other news vs. Science news (average daily).

$\boldsymbol{R} \boldsymbol{Q}-7$ A comparative study in the number of all other news vs. Science news (average daily) where news source is the news agency only.

\begin{tabular}{|c|c|c|c|c|}
\hline Research Question & \multicolumn{2}{|c|}{ Asia } & \multicolumn{2}{c|}{ Africa } \\
\hline 6 & 92 & 2 & 86 & 1 \\
\hline 7 & 13 & 2 & 35 & 1 \\
\hline
\end{tabular}

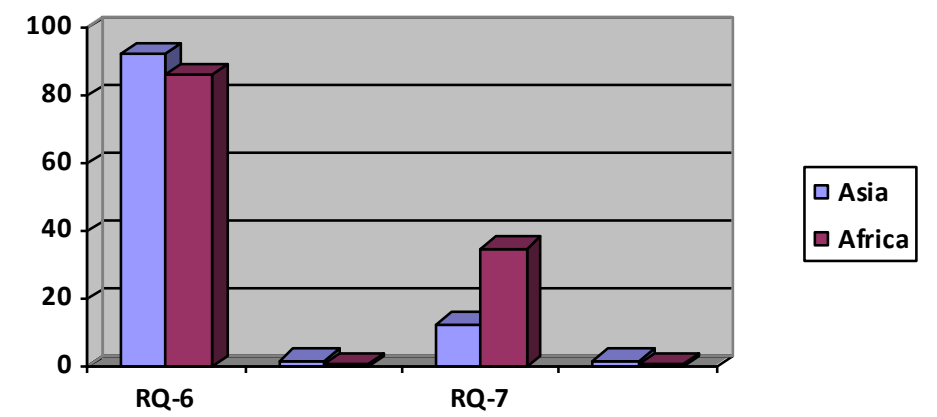

Diagram5. Comparative study of $R Q-6$ and $R Q-7$ on science news in Asia and Africa

$R \boldsymbol{Q}-\boldsymbol{8}$ A comparative study of space shares in column-centimeter of those all other news vs. Science news, where news agency is the only news source.

RQ-9 Among science news only, comparative study of news sources between news agency and own correspondent.

\begin{tabular}{|c|c|c|c|c|}
\hline Research Question & \multicolumn{2}{|c|}{ Asia } & \multicolumn{2}{c|}{ Africa } \\
\hline 8 & 34 & 83 & 59 & 96 \\
\hline 9 & 14 & 86 & 5 & 95 \\
\hline
\end{tabular}

$R Q-10$ Variety of science news as published from news agency.

\begin{tabular}{|l|l|l|l|l|l|l|l|l|}
\hline & Med Sc & Agri Sc & Spac Sc & Phy Sc & Bio-tec & Bio Sc & Earth Sc & Def Sc \\
\hline Asia & 34 & 15 & 8 & 4 & 18 & 15 & 5 & 1 \\
\hline Africa & 29 & 8 & 13 & 6 & 22 & 16 & 3 & 3 \\
\hline
\end{tabular}
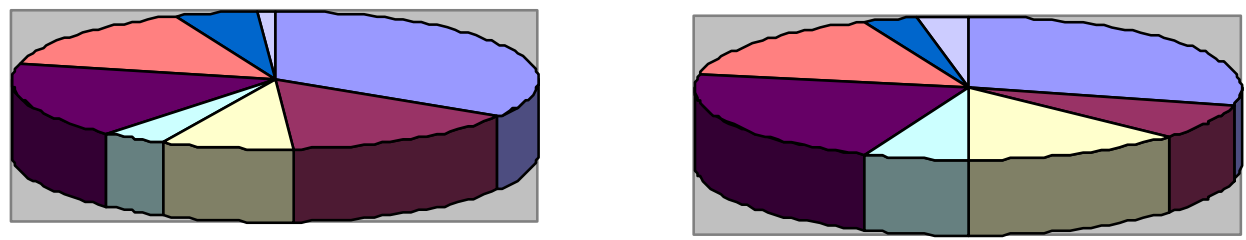

Diagram6, 7. Comparative study of $R Q-10$ on science news in Asia and Africa

\section{CONCLUSION AND LIMITATION}

It has been found that the Middle East is by almost any reckoning the world's worst region for freedom of expression, even compared to South-east Asia, even if it is the question of science communication also. Same or worse condition prevails in African countries also. In the countries like Angola, Ethiopia, Senegal, Mongolia, Morocco, Tunisia and Sudan the science communication scenario is too weak and they mostly depend on the news agency sources and even their news agency is controlled by their government. Religious point is also there in some African countries. For Middle 
East Asian countries, this scenario is most alarming, because there is strongly religious and Government intervention. When some of the South-east Asian countries have repeatedly declared their intention to clean up environment, gender equality, eradication of child labor, increasing literacy, more emphasis on local regional language journalism on very local science issues, more scientific movements, following UN Declarations on several times, honest and free-fare election for democratic Government and free from any pressure from any religion; middle-east Asian countries are far lagging behind. Even, for India-Bangladesh-Pakistan-North Korea-Afghanistan of South-east Asian countries, this picture is not very satisfactory. Hence, it can be concluded that, most circulated newspapers also do not recruit science journalist as specialist and even they do not publish the specialized articles on popular science also. Scenario of Asia is better than Africa, but not up to the mark. Compared to all other news like crime, sports, political, military and defense etc, for science news, newspapers mostly depend on agency sources and least space is given in middle pages, not in front pages. It is also found, when for all other types of news, most newspapers fully depend on their own sources and own correspondents, for science news only newspaper managements narrow down their dependence on news agency only.

This study has some limitations. As it is impossible to read all languages of all the countries, there may come some minor statistical error, when considering newspaper of regional languages. Also, apart from capital cities, all other major cities were not been considered for this sample survey.

\section{REFERENCES}

[1] Burns, T.W. O'Connor, D.J. Stocklmayer, S. M. (Ed.). (2003). Science Communication: A Contemporary Definition. Public Understanding of Science, Vol.12, No.2.

[2] Chandana Chakrabarti and P. Bhargava, Science and Technology as Determinants of Peace.

[3] Cribb, J. (2007). Obstacles to Science Communication. Research and Media Network, 1 June. Retrieved January 25, 2013, from http://researchandmedia.ning.com/forum/topics/701094: Topic:6821

[4] Evertsson, M., P. England, I. Mooi-Reci, J. Hermsen, J. D. Bruijn and D. Cotter (2009), "Is Gender Inequality Greater at Lower or Higher Educational Levels? Common Patterns in the Netherlands, Sweden, and the United States”, Advance Access publication April 29, 2009, Oxford University Press.

[5] Intodia, S.L. \& Upadhyaya, R. (1991). The Village Contact Drive. A Technique in Rural Communication, Rajasthan College of Agriculture, Udaipur.

[6] Z. P. Yin, "The philosophy of science communication studies," Ph.D. dissertation, Dept. Philosophy of Science and Technology, Fudan University, China, 2004.

[7] D. Y. Zhang, S. L. Tao, and Z. Y. Guo, Introduction to Science Popularization, 1st ed, Beijing China: Peking University Press, 1983, ch. 1, pp. 38.

[8] Biswas, S. (2012). Why are India's Media under fire? BBC News India. Retrieved 12 March 12, 2013, from http://www.bbc.co.uk/news/world-asia-india-16524711

[9] Burns, T.W. O'Connor, D.J. Stocklmayer, S. M. (Ed.). (2003). Science Communication: A Contemporary Definition. Public Understanding of Science, Vol.12, No.2.

[10] Chandana Chakrabarti and P. Bhargava, Science and Technology as Determinants of Peace.

[11] Unesco, "Castasia II, statistics on scientific and technical manpower and expenditure for research And experimental development activities in selected countries and territories in Asia and the Pacific" (Paris, 1982).

[12] Y. Yuthavong, J. Sci. Soc. Thailand 5, 53 (1979).

[13] A. Arbhabhirama, Y. Yuthavong, A. Jitjang, S Ketudat, "Reflections and expectations on development and development research," report submitted to the International Development Research Centre, Ottawa, September 1983.

[14] M.M. Gore and A. Mishra, Vigyan katha ka Safar, Manjuli Prakashan, New Delhi (2000).

[15] Kipping, P. (1996, Jan-Feb). Media Literacy - An Important Strategy for Building Peace. Peace Magazine, 12(1), 23

[16] Livingston, Morna \& Beach, Milo (2002), Steps to Water: The Ancient Stepwells of India, Princeton Architectural Press, ISBN 1-56898-324-7. 
[17] Lock, Stephen etc. (2001), The Oxford Illustrated Companion to Medicine, Oxford University Press, ISBN 0-19-262950-6.

[18] Finger, Stanley (2001), Origins of Neuroscience: A History of Explorations Into Brain Function, Oxford University Press, ISBN 0-19-514694-8.

[19] Kearns, Susannah C.J. \& Nash, June E. (2008), leprosy, Encyclopædia Britannica.

[20] Kenoyer, J.M. (2006), "Neolithic Period", Encyclopedia of India (vol. 3) edited by Stanley Wolpert, Thomson Gale, ISBN 0-684-31352-9.

[21] Khan, Iqtidar Alam (1996), Coming of Gunpowder to the Islamic World and North India: Spotlight on the Role of the Mongols, Journal of Asian History 30: 41-5 .

[22] Kieschnick, John (2003), The Impact of Buddhism on Chinese Material Culture, Princeton University Press, ISBN 0-691-09676-7.

[23] Kriger, Colleen E. \& Connah, Graham (2006), Cloth in West African History, Rowman Altamira, ISBN 0-7591-0422-0.

[24] Livingston, Morna \& Beach, Milo (2002), Steps to Water: The Ancient Stepwells of India, Princeton Architectural Press, ISBN 1-56898-324-7.

[25] Lock, Stephen etc. (2001), The Oxford Illustrated Companion to Medicine, Oxford University Press, ISBN 0-19-262950-6. 